AWEJ for Translation \& Literary Studies, Volume3, Number2.May 2019

DOI: http://dx.doi.org/10.24093/awejtls/vol3no2.1

Pp. 2-13

\title{
Connection and Disconnection in Tom's Midnight Garden
}

\author{
Mouhiba Jamoussi \\ Faculty of Language Studies, Arab Open University \\ Kuwait
}

\begin{abstract}
This paper entitled 'Connection and Disconnection in Tom 's Midnight Garden' aims to challenge a particular reading of Philippa Pearce's novel Tom's Midnight Garden (1958) as nostalgic and concerned with aging and death. Tom 's Midnight Garden is regarded by some literary critics as a nostalgic work concerned with the past rather than the present. Its protagonist Tom is sometimes considered as disconnected from the real world and living in the fantastic. This paper will argue that, quite the contrary, Tom's Midnight Garden stands against disconnection, between the child and the adult, the fantastic and the real, and the past and the present. Tom's Midnight Garden celebrates connection through the interrelation between the self and the other, through a fantastic world constantly interwoven with the real, and a past tightly tied to the present. This paper relies on a thorough reading of the novel, on findings on the child-adult relationship, and on the effects of connection and disconnection on the individual.
\end{abstract}

Keywords: $20^{\text {th }}$ century children's literature, connection and disconnection, fantastic and real, Philippa Pearce, tom's midnight garden

Cites as: Jamoussi, M. (2019). Connection and Disconnection in Tom's Midnight Garden. Arab World English Journal for Translation \& Literary Studies, 3 (2) 2-13.

DOI: http://dx.doi.org/10.24093/awejtls/vol3no2.1 
AWEJ for Translation \& Literary Studies Volume, 3 Number 2. May 2019

Connection and Disconnection in Tom's Midnight Garden

Jamoussi

\section{Connection and Disconnection in Tom's Midnight Garden}

Philippa Pearce's (1920-2006) novel Tom's Midnight Garden is regarded by some literary critics as a nostalgic work concerned with aging and death, and with the past rather than the present. Its protagonist Tom is sometimes considered as disconnected from the real world and living in the fantastic. This paper will argue that, quite the contrary, Tom's Midnight Garden celebrates connection through the interrelation between the self and the other, between the fantastic and the real, and between the past and the present.

Some literary critics consider Tom's Midnight Garden as nostalgic and melancholic. According to Montgomery (2009), literary critics find that Tom's Midnight Garden positions Victorian England as a "lost golden age," and that scholarly interest in Tom's Midnight Garden has centered on the themes of "things slipping away," "ravages of time," and melancholy ( $p$. 204). Montgomery herself believes that childhood is a "transient phase of life that can never be revisited," and that Tom's Midnight Garden is haunted by death and "imbued with a feeling of loss and longing for the past" (p. 204). Nikolajeva (2009) mentions the winter scene in Tom's Midnight Garden as signaling "the inevitable movement toward growth, aging, and death" (p. 216), and argues that "Tom staying in the garden would be the same as dying" (p. 219).

As we will try to show below, Tom's Midnight Garden is far from being nostalgic, or concerned with loss and death. It celebrates life and connects the child and the adult, the fantastic and the real, and the past and the present. Tom's Midnight Garden does haunt: it has haunted me personally ever since I read it, but not because of ghosts or fear of death-Tom's Midnight Garden moves, delights, instructs, and heals. The dramatist David Wood (2011) who adapted Tom's Midnight Garden for the stage also describes it in one of his interviews as a "haunting book" which fascinates. In "Loneliness, dreaming and discovery," Rustin and Rustin (2009) agree that Tom's and Mrs. Bartholomew's experience is not loss or death, but what we may call rebirth, with Mrs. Bartholomew, like Tom, emerging "from this deadness to the discovery of love buried or frozen within her" (p. 211). Rizq (2001) too insists that this novel is "not about a loss of enchantment," but rather "a recognition of its continuing power, importance and potential meaning in a life" (p. 494).

Tom's Midnight Garden is indeed neither nostalgic nor sad. In one of her interviews, Pearce (1985) explains that, like most writers, she based her novel on her childhood environment - a beautiful nineteenth-century house, and a garden that gave "safety for the child," which became her "inspiration" for Tom's Midnight Garden (p. 75). One may even suggest that writing about the house and the garden was for Pearce a way of coming to terms with the pain of having to move away from her childhood home. Pearce also expresses her joy that the house was still inhabited by someone who loves it very much, thus not expressing regret but sharing the new home-owners' happiness. She herself spent her later years in a cottage opposite this house. So far from being nostalgic, Pearce remained connected to the house throughout her life, and made it for ever present in Tom's Midnight Garden.

Not surprisingly then, Pearce (1985) considers Tom's Midnight Garden "not at all sad" (p. 86) and finds pain and sadness rather in the real world and in the real fictional world of the

Arab World English Journal for Translation \& Literary Studies

ISSN: 2550-1542 | www.awej-tls.org 
novel: "Power is the thing," she concedes in this interview, and children are "powerless" though they "have such potential and such strong impulses and emotions," and Tom knows he is "being manipulated in a way, like a dog put in kennels" (p. 84). Her interviewer Geraldine Deluca suggests that Hatty is sad and alone at the end, but Pearce responds: "Well, we are all alone at the end, aren't we?" (p. 86). As for Roni Natov, the other interviewer, he reveals that he cries every time he reads Tom's Midnight Garden, but adds 'I'm not sure I cry because it is sad. I think it evokes deep emotions... there is something so incredibly moving" (p. 86). It is precisely because in the real world and in the real fictional world of the novel children are powerless and the old are alone that Tom and Hatty (Mrs. Bartholomew) enter the fantastic garden, which empowers them and gives them a much-needed companionship.

The fantastic world of Tom's Midnight Garden is tightly related to the real world. According to Pearce (1985), there are no real differences between writing fantasy and writing realism (p. 83), thus connecting the two worlds. She explains that her use of time in the fantastic garden is based on a "perfectly respectable hypothesis of time" in J. W. Dunne's Experiment with Time (published in the twenties) and which she heard her older brothers discuss with friends when she was young: "It sounded interesting and rather mysterious. It was about serial time, about how different times coexist together" (p. 78). For her, Tom's Midnight Garden works "more effectively" because it is not totally realistic, at the same time, she never thinks of it as a "fantasy" (p. 78). Indeed, as will be shown below, Tom's Midnight Garden does not attempt to distinguish, but rather connects, the real and the fantastic, the ordinary and the magical. Tom's Midnight Garden also connects different generations: Pearce explains in her interview that Tom's Midnight Garden is "an attempt to reconcile childhood and old age" and "to bring them together" (p. 79). In 2000, when asked about her works, Pearce still sounds, at the age of 80, "as powerful a communicator with children" as ever (still exploring).

The power of Tom's Midnight Garden is indeed in more than one reconciliation. It is reconciliation between the self and the other, the fantastic and the real, and the past and the present. Tom and Hatty, each frustrated and lonely, meet through imagination and memories, in a world where the fantastic and the real intermingle, and where historical periods crisscross. We are invited to question our views on empathy and growth, on the link between the fantastic and the real, and on the connection between generations past and present.

From the very beginning of Tom's Midnight Garden, all adults seem to be taking care of Tom and making their best to please him, but Tom looks and sounds quite unhappy. From page one, Tom is being sent to "Exile" as the title of the first chapter tells us, with a tie, i.e., a knot, round his neck (p. 1). After being sent away from home, Tom is no longer in contact with mother or father-both remain practically absent throughout the whole novel. It is only with his brother Peter that he remains connected, exchanging secrets in daily letters.

The encounter with Uncle Alan and Aunt Gwen proves not particularly happy. The Kitsons live in a house turned into flats, and Tom feels "a chill" in the "silent" and "unwelcoming" hall of a house whose heart is "empty—cold—dead" (p. 5). Aunt Gwen, a kind child-lover, as we are often reminded, tries to make Tom feel at home, but nothing seems to work. Tom feels treated like a baby, having to comply with rules and regulations over which he 
has no say, which further isolates him and confirms his exile-he feels his self being shattered, eventually becoming "two persons" (p.10). When he decides to comply with the rules, more rules follow, through orders and violence, not explanations. The reader is reminded of the rigid rules of the 1950s English home, which continued long after the 1950s, strictly regulating behavior at home ranging from hours of sleep to leaving the dinner table. Tom therefore decides to disobey but Tom's rebellion is short lived, and it triggers one of the most violent scenes in the novel.

Tom is overpowered and silenced, and so he starts 'hating' his uncle and feeling he is in the "worst hole," "imprisoned in wakefulness," with nothing to do, nowhere to go, and nobody to do things with (p.14). This is what the psychotherapist Jordan (2001) refers to as an "acute disconnection" when "people fail each other empathically, do not understand, or let each other down," and she illustrates this disconnection with the example of the unequal parent-child relationship (p. 95). When disconnection becomes chronic, Jordan explains, the child feels "less real, less seen, and less understood" (p. 96), and this is what happens to Tom. He feels isolated, only connected to the grandfather clock which speaks to him in these "hours of darkness"-_ "still ticking, still alive... senseless" (p. 15) unconcerned with the rules of reasonableness at the Kitsons' flat. So when he hears it strike thirteen, he decides this is an "hour of freedom" (p.15) and leaves the flat. The garden Tom discovers indeed frees him and empowers him: it reconnects him to nature, and offers him space and safety away from the tiny flat and from everyone's strict rules and regulations.

The fantastic world of the garden is exactly how Tom wants his real world to be. What happens to him confirms that fantasy truly "speaks to our dreams and deepest desires" (Roslan et al., 2016, p. 221). Writing about satisfying human desires in fantasy, Ashitagawa (2009) asserts that the fantastic "consists in what is denied and desired in the 'real' world" - the need to survey the "depths of space and time," and "to hold communion with other living things" (p. 39).

The discovery of the garden is accompanied by some magical happenings but Tom is only concerned with the garden, and that is "real" (p. 24). Tom becomes momentarily invisible and inaudible, and the hall empties itself of furniture, but the garden reminds Tom of home, of Christmas and the New Year. Wolf (1982) explains that contrary to most fantasies, Tom's Midnight Garden does not use rational explanations to be credible: "Pearce gradually inspires belief without sacrificing any of the imaginative power of the mystery she unfolds," she writes, and "much of Tom's Midnight Garden's credibility arises from Pearce's limiting us to Tom's point of view" (p. 142). Indeed, as mentioned above, Pearce never intended to write a fantasy, and so Tom's Midnight Garden is rather a magical realist novel where supernatural events are not doubted. Watson (2000) explains that studies of magical realism tell us that the narrator "neither censures nor shows surprise," that he is accepted as reliable because "he does appear to give an accurate portrayal of a different mentality" (p. 167). These "quirky things," as Campbell (2015) puts it in her video on magical realism, are simply "taken as given." It is also suggested that, through focalization, Tom's experiences in the garden are "believable within the framework of Pearce's constructed world" (Study Guide, 2009, p. 171). The reader is then likely to believe the garden is real and not to question what Tom is ready to accept.

Arab World English Journal for Translation \& Literary Studies 
The garden gives Tom extreme happiness, at the same time it further distances him from the Kitsons: his "surprise" when he discovers the garden turns into "indignation": he thinks they "deceived" him and "lied to him" (p.19), so he decides to shame them. The confrontation that follows is for Tom one between him and those "wrongdoers," whereas for them it is between adults and a child who needs to "grow up" (p. 27). While the uncle and aunt fail to believe what Tom is describing, the reader is, as in any magical realist novel, ready to accept fantastic elements that do not particularly surprise the narrator or the focalizer. The fantastic is indeed "another door into the truth" (Rushdie, 2015). It provides "a fresh perspective on the real world," "a different way of apprehending existence," and is not less true than the real (Roslan, 2016, p. 221). Ashitagawa (2009) goes further, explaining that the fantastic is "the other side of the real," and that it even "flips over to be the "most real"" (p. 30).

Discovering the garden brought an end to Tom's isolation and loneliness, and even when he thinks it is no longer there, he is determined to find it. For Natov (2009), what drives Tom to look for the midnight garden is "the ordinary and too common isolation of childhood": Tom "is every child, tyrannized by adult reason," and whose hopes are betrayed by the "impenetrability and tediousness of adults" (p. 221). Elements that seem unconnected and irrational come together - a clock striking "hours and hours that don't exist" as if having "lost all count of time," Mrs. Bartholomew dreaming of her childhood, and Tom entering the garden that he knows is "waiting for him" (pp. 34-35).

When Tom rediscovers the garden, he is finally happy-the garden is now "his" (p.35) and its inhabitants his new companions - birds that speak and geese that greet the new morning. Tom's garden is certainly fantastic but real-it does not surprise him, for instance, that his own footsteps leave no trace on the lawn. After reviewing several magical realist novels, Bell-Villada (2014) finds that the reader encounters in these novels the supernatural not as an "intrusion" but as a "component part," and that magical things "really happen," are "really there": "We are not in an alternate world," Bell-Villada explains, and so magical realism is "a fusion," "not an oxymoron," a world where the supernatural is "not presented as problematic" and "does not disconcert the reader" (p. 53).

What Tom discovers further connects him to the fantastic world of the garden. He finds out that all the time spent outside the flat only shows as few minutes on the kitchen clock, which puts an end to his fear to be late. He is invisible and inaudible but he can see people, and is seen and heard by animals. He cannot open doors but he can go through them, and he can climb walls and go and explore the wood beyond the garden. The garden therefore offers Tom all that he was longing for and could not have in his real world - unlimited freedom, space, time, and company. According to Eşberk (2014), studies of fantasy reveal that fantasy refuses to observe unities of time, space and character, thus "doing away with chronology, three dimensiality and with rigid distinctions between animate and inanimate objects, self and other, life and death" (p. 141).

Tom is not disconcerted by what he discovers in his new environment. He finds the garden and its surroundings not outside "the natural order of things" (p. 51), though he wonders why for instance time of the day in the garden is not the same as time in the flat. As Zipes (2009) explains, we have always tried to make sense of the world through fantasy, not through reason: 
"Reason matters, but fantasy matters more" (p. 78). Tom realizes once again the limits of reason in his real world when he tries to discuss what he has observed in the garden with his aunt and uncle. His questions trigger a long heated debate, followed by greater tension, and total disconnection between Tom and the Kitsons. Uncle Alan finds Tom's questions "odd," and "lacking connection" and "seriousness" (p. 56), and Aunt Gwen typically links these questions to fairy stories and queer dreams. Tom is shocked but he continues to maintain that what he has seen is all "real" (p. 57).

Tom is emboldened by the fantastic to stand for what he believes to be true, which is not surprising. Zipes (2009) asserts that "we need the fantastic for resistance" (p. 79), and Eşberk (2014) depicts the nature of the fantastic as "rebellious" (p. 143). Tom's Midnight Garden, it is argued, helps answer a fundamental question about the fantastic: "Is it simply any departure from reality, or will the best fantasy in some way provide insights into reality, or even undermine it?" (Study Guide, 2009, p. 170). The increasingly violent arguments between Tom and the Kitsons are clear evidence that they are worlds apart-Tom now lives in a different space and a different time.

The fantastic garden gradually becomes more real than the real. It becomes home, and Tom fears to go back to his real home which "seems a long, long misty way away" or to his brother Peter by now a "remote boy" (p. 60). Kurkjian et al. (2006) argue that despite some "bizarre situations," fantasy helps us "better understand reality" (p. 492). Tom now understands for instance that invisibility is a form of freedom. He can reconcile the two Toms which make one again. Fantasy, Ashitagawa (2009) explains, is the exploration of the "inner self" and the "unknown in the mind" (p. 33). It is where "the ordinary and the extraordinary meet," where Tom "reconstructs the lost harmony of his childhood" (Natov, 2009, p. 222). The connection with the garden allows Tom to heal, and when he later meets the little girl Hatty, the garden becomes even more significant and more fantastic.

Hatty turns out to be an ideal companion and her games not "silly girls' games" (p. 73). Like Tom, she feels isolated and lonely and is looking for a playmate. She can see Tom and hear him, so Tom can now connect with a human, not just with nature and animals, which makes the garden more real. Hatty gives a sensible explanation to Tom's queer feeling that he was watched, which makes anything senseless in the garden likely to prove sensible. Hatty is an excellent story-teller, telling stories from the Bible and fairy tales and calling herself "Princess Hatty" (p. 71) which Tom does not mind. More importantly, Hatty is an expert on all matters pertaining to the garden, and a very clever partner. Tom too has skills to offer. He teaches Hatty how to make a bow and play shooting games, and how to climb trees. She is triumphant on top of Tricksy and he is jubilant on top of a high wall "gazing freely about him," walking "like a king" (p. 120)for Tom, Hatty might not be a princess, but she has certainly made his garden "a kind of kingdom" (p. 81).

The relationship between Tom and Hatty allows both to enjoy the garden like never before, and to mature and grow. Contrary to traditional theories of psychological development which stress the importance of autonomy, separation, and self-sufficiency, Jordan (2001) explains, the relational-cultural theory proves that "maturity involves growth toward connection and 
relationship throughout the life span" (p. 92). According to this theory, most people suffer because of isolation, and so healing comes through connection and mutual empathy. Basing his analysis on the same theory, Ben Moussa (2016) explains that Pearce does not see the self existing without the "other": in his connection with Hatty, Tom's individuality is not threatened but rather asserted, and his empathy is an "important factor in his growing up, in constructing his identity, and in shaping his relational self through reaching out to the 'other', Hatty" (p. 33).

Tom's and Hatty's joy and happiness is sometimes interrupted, but not their communion and empathy. For instance following the damage done to the flower-beds and the lawn, for which they are responsible, Hatty's aunt insults and humiliates Hatty who stands isolated, while Tom, invisible and inaudible, cries out at "his own powerlessness and fears" (p. 94). Tom finds Hatty worse off than him, though he often encounters violence at the Kitsons. Pearce reminds us here of the well noted harsh educational approach in Victorian times. She also draws the reader's attention to the blame put on the poor, in the class-ridden Victorian society, for their poverty and for being a burden on others. Only with the advent of the post-war welfare state did poverty, together with the blame put on the poor, come to be considered unfair and unacceptable in Britain. This incident which causes so much pain to both Tom and Hatty is at the same time an extraordinary moment of empathy. When Tom later meets little Hatty in black, and sees a grief never seen before, he decides he will always let her claim she is a "royal exile and prisoner" ( $p$. 97).

Tom's life in the fantastic gives him confidence and enforces his agency. He decides to overstay for some more time, thus disrupting his family's earlier plan. He ignores the Kitsons' attempts to understand or to amuse him, which could have been appreciated had they come at an earlier stage. Outings arranged by Tom's aunt further distance him from the real world: for instance the river once clear and pure is now polluted (Pearce stands as an early environmentalist, drawing our attention to the need to preserve nature). So Tom prefers to live his "real and interesting life" (p. 99) at night in the garden, and to have during the day "only peace" (p. 100) to think of the garden. When he is sick, it is the greenness of the garden which has a soothing and healing effect on him.

Nevertheless, the garden and Hatty remain quite enigmatic to Tom, and he sometimes wonders if they are not all ghosts. Tom decides therefore to confront Hatty about this matter, but this leads to a very heated argument, with each one of them angry and resentful, accusing the other of being a ghost. Tom insists that the whole garden is a ghost, and that Hatty is "dead and gone and a ghost!" (p. 107). Hatty, who seems to have grown so much, calls Tom a silly little boy. But this unique confrontation, instead of disconnecting them for good, brings them closer together-Tom is moved by Hatty's tears and decides not to reopen a subject that upsets her so much. This scene, Natov (2009) suggests, is meant to show the need to respect "otherness," to show that there is "more than one reality," and that "neither the self nor the other is... a 'ghost,' but rather that both are real" (p. 224). "The self and the 'other' are not mutually exclusive," Ben Moussa (2016) argues, "one does not necessarily cancel out the 'other' in order to exist," and both "can share the same space in a comfortable inter-dependent relationship of mutuality and respect” (p. 38).

Arab World English Journal for Translation \& Literary Studies 
This confrontation results in greater connection which corresponds to Jordan's (2001) observation: when a serious disconnection is addressed, it can actually lead to "strengthened connection" (p. 95). Indeed, following this confrontation, Tom feels greater empathy and admiration towards Hatty, and is impressed by Hatty's particular argumentation, so he embarks on a "pursuit of knowledge" (p. 108). He also becomes more attached to Hatty and feels that without her, the garden seems "a green emptiness" (p. 114). The tree-house Tom and Hatty decide to build is to be their own house-Hatty's home and her best hiding-place in the garden.

Another disruption in Tom's and Hatty's relationship is when Hatty falls, and Tom finds himself in another period of time when he visits her. Everyone Tom meets has grown much older, and the aunt looks like a stepmother or witch in a fairy tale. She unsurprisingly puts all the blame on Hatty for her fall and for not growing up. Her cousin James tries to defend Hatty: she should be allowed to earn her own living, or make acquaintances and marry. This scene once again plunges us into an upper-class Victorian family where the family power structure allows the head of the family, Hatty's aunt here, to rule and to force all members of the family to obey through moral and financial blackmail. We are given a whole range of leisure activities offered to upper-class young men and women but in which Hatty is not participating because she does not truly belong to that class. Like these young women, Hatty is not supposed to earn a living, but unlike them, she does not have a chance to meet a future husband who would be her financial supporter. Pearce thus reveals the traps in which Victorian young women could find themselves, and their likely financial dependence later within marriage.

In this period of time, Tom fears he and Hatty are growing apart. She is delighted to see him, but she has grown much older, and is indeed planning to take part in activities of people of her age. Besides, though Tom is warmly welcomed, he is grateful to find himself the next morning in his own world. Matters seem rather complex and choices not easy to make: Tom wishes to stay longer in his fantastic world, but he misses his family and his home- "a desperate situation" where time is both his "friend" and his "enemy" (p. 157). When Tom later meets Hatty, they disagree on the meaning of "Time no longer" (p. 164) — she thinks it means the end of the world, and he thinks it may have more than one meaning.

Throughout Tom's Midnight Garden, the fantastic gives space and time for Tom to better understand the real, or to rebel against the real, but at this later stage, the fantastic leads to very sophisticated discussions of extremely complex issues. Roslan et al (2016) argue that "Through fantasy we are able to group, explain, alter and comment on reality" (p. 212), and to engage with "genuine problems in the real world" (p. 221). Eşberk (2014) quotes several critics on the role of the fantastic in creating the need to "search, resist, think and criticize" (p. 143), and on the proper function of fantasy to "transform this world" (p. 142). Indeed, for the first time, Tom leaves behind Hatty and the garden and goes back to the Kitsons' to think about the issue of Time.

Once again, Tom goes to his uncle and aunt for an explanation: "What is Time?" (p. 167). As usual, his aunt's answer is simplistic and his uncle's confusing, and this leaves quite a wide gap between them and Tom. The uncle's theories confuse and depress Tom, and Tom's mention of angels makes his uncle angry and violent. Whereas Tom's encounters with Hatty allow him to grow and mature, every encounter with the Kitsons reduces him to a child. Tom seems to be 
gradually entering into what Jordan (2001) calls "chronic disconnection," feeling "ineffectual and helpless" (p. 96). Once again his uncle's theories do not help, but what the angel reveals to him in his dream, and what he discovers through literature, do help him understand time: his case is Rip Van Winkle's but in reverse. He realizes that in the garden, he stepped back into the Past, Hatty's time, and Hatty stepped into the Future, his Present. So he concludes they are all real: "We are neither of us ghosts; and the garden isn't either" (p. 171).

Pearce here fully attacks post-war fascination with the rational, and rather celebrates religion, literature, and even dreams in helping better understand complex issues. In the last lines of her book chapter on the fantastic, Whitehead (2012) asserts that the role of the fantastic is to challenge earlier wisdoms - "notions such as the hegemony of post-Enlightenment rationalscientific discourses," and "the dominance of monolithic constructions of truth and reality" (p.15). The aim of the fantastic, she adds, is "to empower readers to construct alternative discourses," and "to question the existence of a single truth" (p. 15).

While Tom's relationship with the Kitsons further deteriorates, he remains fully connected to Hatty. Hatty accepts to leave her skates, at Tom's request, in her own cupboard where Tom will later find them. Even in his dreams, Tom is still in Hatty's world where he is skating to the end of the world, and the end of time. Next time she sees him in the garden she tells him she is waiting for him, wishing to see him and no one else, and Tom chooses to go skating with her rather than enter the garden. Later their skating on a single pair of skates and in total communion is to Tom "the eeriest" yet "the most natural thing in the world," giving Tom a "new skill and power" and Hatty freedom from "muffs or improprieties or aunts" (p. 188).

This scene is ironically followed by disconnection and great pain by the time they reach Ely Cathedral. Tom's brother who joins them at the Tower points out that Hatty is a grown-up woman not a child, while Hatty finds both brothers hardly visible. Tom is speechless and when he speaks it is to defend himself and Peter: "He's real, like me. You agreed I was real, Hatty" (p. 196). But doubt and concern are now replacing the extraordinary connection that the two enjoyed on their way to the Tower. Anxiety and fear increase when they leave the Tower, and by the time the new friend Barty takes them home, Hatty ceases to see Tom, and Tom feels isolated and lonely.

Tom becomes aware that though time is endless, he is no longer sure of mastering it and living in the garden forever. Indeed, next time he tries to enter the garden, the garden is gone. He springs, turns, and runs, "like a rat with the dogs after it" (p. 209), and when carried by his uncle, he cries and feels like someone "taken prisoner," going back into exile (p. 210). As usual, his uncle and aunt totally fail to understand what he is going through, and he is not ready to share his story with them. But when Tom decides to apologize to Mrs. Bartholomew for the noise he made, his tone and manner force them to respect his wish.

When Tom and Mrs. Bartholomew meet, they immediately reconnect-Mrs. Bartholomew realizes Tom is a "real, flesh-and-blood boy" (p. 215) and Tom understands they were "both real," "then and now" (p. 224). This is a great moment of epiphany about the self and the other, concerning existence and co-existence: one can be, and still let the other be. Mrs. Bartholomew 
is a more mature Hatty: "nothing stands still, except in our memory" (p. 221), she tells Tom. Tom too sounds, through his questions and answers, much more mature. Writing about the experience of growing up in Tom's midnight Garden, the therapist Rosemary Rizq (2001) celebrates the role of the fantastic in this novel, and asserts that Tom's Midnight Garden reminds us that growing up is "truly a counsel of despair, a sell-out, a loss" (p. 494). She insists that contrary to traditional psychoanalysis for which growth is a "journey from infantile dependence to independence," and "from fantasy to reality," we should "keep alive that enchanted place...within ourselves," and that this place "can and must remain active and meaningful within us as adults" (p. 494).

Tom's and Mrs. Bartholomew's reunion illustrates once again how the fantastic is interwoven with the real. They resume fantastic stories left unfinished, stories about the Victorian home whose garden was replaced by houses, and whose furniture was scattered-a house which ceased to be "a gentleman's house" (p. 222). Acquiring the Melbournes' house also sounds like Hatty's revenge on her aunt, and Pearce's revenge on a Victorian class-ridden society. Any reference to the Victorian upper class is rather sarcastic, and the working class is not spared either: Abel the gardener and the maid Susan had a large family and lived happily ever after. Mrs. Bartholomew also speaks of the loss of her two children in the Great War, a pain shared by a whole generation of mothers. Tom's Midnight Garden is thus far from celebrating the past and from being nostalgic.

Tom is now closer to home, but his reconnection with Hatty is now symbolized by the affection between him and Mrs. Bartholomew. They now have a past of their own which can always be there to remember, and future plans of reunion. Tom and his brother seem to "bring alive her two lost sons," it is suggested, and Mrs. Bartholomew comes back as the "internal mother [Tom] has lost and found" (Rustin \& Rustin, 2009, p. 211). Mrs. Bartholomew can also simply stand for the grandmother to whom the grandchild Tom rushes to hear stories - past and present generations, separated by the celebrated post-war nuclear family, and which, Pearce reminds us, need to remain connected.

Tom 's Midnight Garden ends with the most moving scene of the novel, a communal embrace between the child and the adult, the male and the female, the Victorian and the post-war friends, who meet in the magical world of the garden, and are now reconnected in the real world of the novel. The fantastic turns to a reality Tom and Hatty live in, with the promise of remaining connected and meeting again in the future. The reader ends the novel keeping in mind the promise that whenever lonely, there will always be some space, some time, for connection: "You look and see nothing, and you might think there wasn't a garden at all; but all the time, of course, there is a garden, waiting for you" (p. 77).

\section{Conclusion}

Tom's Midnight Garden celebrates connection between the self and the other, the fantastic and the real, and the past and the present. Tom leaves a world of loneliness, of solitude, and of disconnection, and enters the fantastic garden where he can heal and grow. Here he connects with nature and its inhabitants, and the most significant encounter is with Hatty who becomes his 
companion, his playmate, and his story-teller. Through their connection in the fantastic world of the garden, both Tom and Hatty feel at home, no longer lonely or sad. Tom's understanding and empathy allow Hatty to surmount her pain and loss. Hatty on her part makes the garden special, and helps Tom in his pursuit of knowledge. Indeed, Tom tries to better understand the real by constantly contrasting it with the fantastic which gradually becomes more real than the real. Thanks to the fantastic, Tom can understand and discuss complex issues such as Time. Philippa Pearce takes Tom and the reader through a journey, comparing present and older times, and selecting what is most formidable, to protect the present and preserve the future. Tom's and Hatty's reunion at the end confirms the connections between the self and the other, the fantastic and the real, and the child and the adult. The garden is not lost forever, nor is the relation between Tom and Hatty. The garden is symbol of connection, empathy, and healing - a garden which, we are promised, will always be there, waiting for us.

\section{About the Author:}

Mouhiba Jamoussi is Associate Professor of Literature. She has an MA in English Literature from La Sorbonne University, and a $\mathrm{PhD}$ in English Language and Humanities from Tunis University. Her research interests include race, gender, and power relations. Her latest publication is a book chapter on Black Skin. She taught at Tunis University, and was later Department Chair at Modern College, Oman. In 2014, she joined AOU, Kuwait Branch, where she currently teaches literature. ORCID ID is https://orcid.org/0000-0002-2321-8200

\section{References}

Ashitagawa, Y. (2009). Can Fantasy Be More Real than Reality? Pennsylvania Literary Journal, Experiments, Summer, 29-51.

Bell-Villada, G. H. (2014). Magic and Realism in History: Magical Realism vs. the Fantastic Today. Magical Realism and Subaltern Studies, Critical Insights, Grey House, 49-64.

Ben Moussa, M. (2016). Connecting with the Other: Empathy in Tom's Midnight Garden, Arab World English Journal (AWEJ) Special Issue on Literature (4), October, 33-42.

Campbell, J. (2015). Magical Realism: Recommendations and TBR.

$$
\begin{array}{llll}
\text { Retrieved July } & 21, & \text { 2018, }
\end{array}
$$

https://www.bing.com/search?q=\%E2\%80\%A2\%09Campbell

Eşberk, H. (2014). The Function of Fantasy as a Subversive Genre in Literature. Journal of Language and Literature Education, 10, 139-144.

Jordan, J. (2001). A Relational-Cultural Model: Healing Through Mutual Empathy, Bulletin of the Menninger Clinic, 65 (1), 92-103.

Kurkjian, C. et al. (2006). Worlds of fantasy. International Reading Association, The Reading Teacher, 59 (5) February 492-503.

Montgomery, H. (2009). Introduction. In H. Montgomery \& N. Watson (Eds.), Children's Literature: Classic Texts and Contemporary Trends (pp. 203-07). New York: Palgrave Macmillan.

Natov, R. (2009). Tom's Midnight Garden. In H. Montgomery \& N. Watson (Eds.), Children's Literature: Classic Texts and Contemporary Trends (pp. 221-26). New York: Palgrave Macmillan. 
Nikolajeva, M. (2009). Midnight gardens, magic wells. In H. Montgomery \& N. Watson (Eds.), Children's Literature: Classic Texts and Contemporary Trends (pp. 216-20). New York: Palgrave Macmillan.

Pearce, P. (1958). Tom's Midnight Garden. OUP.

Pearce, P. (1985). Interview with Philippa Pearce. Interviewed by R. Natov \& G. Deluca. The Lion and The Unicorn, 9, 75-88.

Rizq, R. (2001). Open Space: Tom's Midnight Garden. Psychodynamic Counselling 7, November 491-498.

Roslan, S. M. M. et al. (2016). Fantasy versus Reality in Literature. Arab World English Journal (AWEJ) Special Issue on Literature No. 4 October, 212-223.

Rushdie, S. (2015). Salman Rushdie on Magical Realism. Retrieved July 1, 2018 from https://www.youtube.com/watch?v=EZtdhLndVYg

Rustin, M. \& Rustin, M. (2009). Loneliness, dreaming and discovery: Tom's Midnight Garden. In H. Montgomery \& N. Watson (Eds.), Children's Literature: Classic Texts and Contemporary Trends (pp. 207-215). New York: Palgrave Macmillan.

Still Exploring the Midnight Garden (2000). The Guardian, 14 October. Retrieved June 1, 2018 , https://www.theguardian.com/books/2000/oct/14/booksforchildrenandteenagers

Study Guide: Children 's Literature (2009). Open University.

Watson, G. (2000). Assumptions of Reality: Low Fantasy, Magical Realism, and the Fantastic. Journal of the Fantastic in the Arts, 11 (2) 164-172.

Whitehead, C. (2012). On the Fantastic, Critical Insights: Fantastic, Salem Press, 1-17.

Wolf, V. L. (1982). Belief in Tom's Midnight Garden. Children's Literature Association Quarterly, 1982 Proceedings, 142-146.

Wood, D. (2011). Staging TMG: Interview with the dramatist David Wood, EA300 DVD, Children's Literature, Open University.

Zipes, J. (2009). Why Fantasy Matters Too Much. The Journal of Aesthetic Education, 43 (2), Special Issue on Children's Literature, Summer, 77-91, University of Illinois Press.

Arab World English Journal for Translation \& Literary Studies 